NOTE

\title{
Gray whales may increase feeding opportunities for avian benthivores
}

\author{
Eric M. Anderson*, James R. Lovvorn \\ Department of Zoology and Physiology, University of Wyoming, Department 3166, 1000 E. University Avenue, \\ Laramie, Wyoming 82071, USA
}

\begin{abstract}
Feeding by gray whales Eschrichtius robustus along the eastern Pacific coast between the Bering Sea and Baja, Mexico, appears to be increasing. Gray whale feeding can disturb large fractions of intertidal and shallow subtidal sediments, altering the distributions of benthic invertebrates for many months. Increased gray whale feeding may be modifying foraging profitability for other bottom-feeding vertebrates along the coast, but such effects have not been documented. This paper is the first report of a feeding association between a cetacean and bottom-feeding birds, namely a migrating gray whale and diving sea ducks. Local counts and condition of surf scoters Melanitta perspicillata in Puget Sound, Washington, suggest that gray whale feeding can provide important foraging opportunities for scoters during spring, when other foods may have declined and requirements to prepare for migration and reproduction are high. Complementary data are needed to evaluate the importance to scoters of this seasonal interaction with gray whales. However, given the large and protracted impacts of gray whales on benthic communities, our observations suggest that whale feeding may have increasing influence on the foraging patterns and trophic relations of a range of bottom-feeding vertebrates.
\end{abstract}

KEY WORDS: Gray whale · Eschrichtius robustus · Birds · Feeding association · Benthic-feeding • Scoters $\cdot$ Melanitta spp.

Resale or republication not permitted without written consent of the publisher

\section{INTRODUCTION}

Gray whales Eschrichtius robustus undertake one of the longest mammalian migrations between their calving lagoons in Baja, Mexico, and summer feeding grounds in the Bering and Chukchi Seas (Rice \& Wolman 1971). Until recently, it was thought that gray whales relied annually on reserves accumulated during summer and that feeding south of the Bering Sea was rare. However, possibly owing to reduced productivity of prey in the Bering Sea and increased foraging needs of an expanding whale population (Moore et al. 2003, Highsmith et al. 2006), observations of feeding during migration and summer from the Gulf of California to the Gulf of Alaska are increasingly common (Sánchez-Pacheco et al. 2001, Calambokidis et al. 2002a, Moore et al. 2007). Among baleen whales (Mysticeti), gray whales are unique in feeding mainly on benthic invertebrates by suction sieving, and their impacts on bottom communities can be profound (Oliver \& Slattery 1985, Weitkamp et al. 1992). Recent genetic evidence that gray whales were far more abundant in the past suggests that they once played a major role in the foraging strategies and distributions of other benthic predators (Alter et al. 2007). Nevertheless, effects of increased gray whale feeding on the foraging patterns of other bottom-feeding vertebrates along the coast have not been documented. The present paper is the first report of an association between cetaceans and birds that feed on the bottom, namely a migrating gray whale and diving sea ducks (Anatidae: Mergini). 
In temperate, polar, and tropical regions, feeding by gray whales and other cetaceans often increases shortterm access to prey for seabirds that feed at the water surface or in the water column (Pierotti 1988, Grebmeier \& Harrison 1992, Pitman \& Ballance 1992). Cetaceans enhance foraging by seabirds in 2 general ways. First, cetaceans often feed where prey is locally abundant (Oliver et al. 1984), so their feeding activities may signal the location of profitable areas (Pierotti 1988). Second, feeding activities of cetaceans can enhance access to prey for seabirds. Seabirds forage on prey that is herded together and forced to shallower depths by cetaceans (Welch et al. 1993), or on prey or prey fragments that cetaceans leave behind (Obst \& Hunt 1990).

Feeding near cetaceans by seabirds may be opportunistic and a minor component of their foraging efforts (Evans 1982), or it may in some cases strongly influence feeding activities at the population scale. During summer in the Bering and Chukchi Seas, foods brought to the surface by feeding gray whales may support hundreds of thousands of seabirds (Harrison 1979), with local numbers of red phalaropes Phalaropus fulicaria and black-legged kittiwakes Rissa tridactyla feeding almost exclusively in mud plumes created by gray whales (Obst \& Hunt 1990). Feeding by Parkinson's petrels Procellaria parkinsoni on remains of fish left by 2 dolphin species may even be obligatory (Pitman \& Ballance 1992).

\section{MATERIALS, METHODS AND RESULTS}

Scoters Melanitta spp. are sea ducks whose North American populations breed on arctic and subarctic wetlands, and in winter dive to feed on benthic invertebrates in shallow marine waters along both coasts (Savard et al. 1998). From 2003 to 2006 we conducted extensive field studies of scoter wintering and migration ecology in northern Puget Sound, Washington, USA. Penn Cove $\left(48.2^{\circ} \mathrm{N}, 122.7^{\circ} \mathrm{W}\right.$; Fig. 1), located near habitual feeding areas for gray whales Eschrichtius robustus, is one of our primary study sites and is one of the most heavily used winter feeding locations for scoters in this region.
We conducted surveys of scoters in Penn Cove during 2003 to 2006 from 11 shoreline stations using a 20 to $60 \times$ spotting scope. Numbers of surf scoters Melanitta perspicillata generally peak at 6000 to 8000 in late fall to early winter in Penn Cove, and decline substantially before regional populations of scoters depart from Puget Sound in April and May (Fig. 2; D. R. Nysewander, Washington Department of Fish and Wildlife, unpubl. telemetry data). In at least some winters in Penn Cove (e.g. 2005 to 2006), numbers of surf scoters are much lower.

On 11 March 2006, near Sandy Point on Whidbey Island (Fig. 1), we observed about 100 surf scoters and 25 white-winged scoters Melanitta fusca diving re-

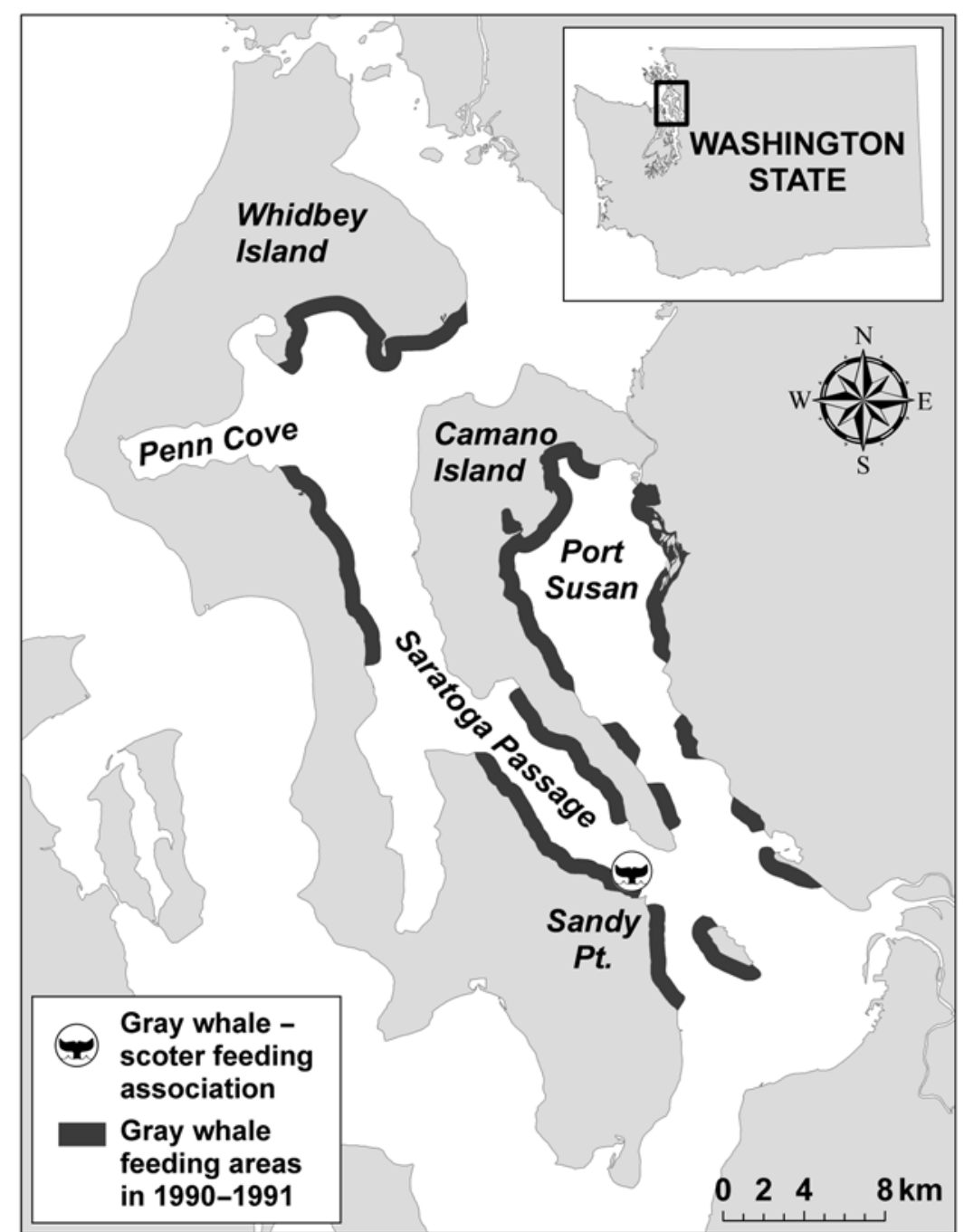

Fig. 1. Eschrichtius robustus and Melanitta spp. Location of a feeding association between a migrating gray whale and bottom-feeding sea ducks in northern Puget Sound, Washington, USA, on 11 March 2006. Locations of gray whale feeding areas in 1990 to 1991 are after Weitkamp et al. (1992). Annual observations indicate that gray whales continue to feed near Whidbey Island each spring, although feeding locations for individual whales may vary among years (Calambokidis et al. 2000, 2002b) 


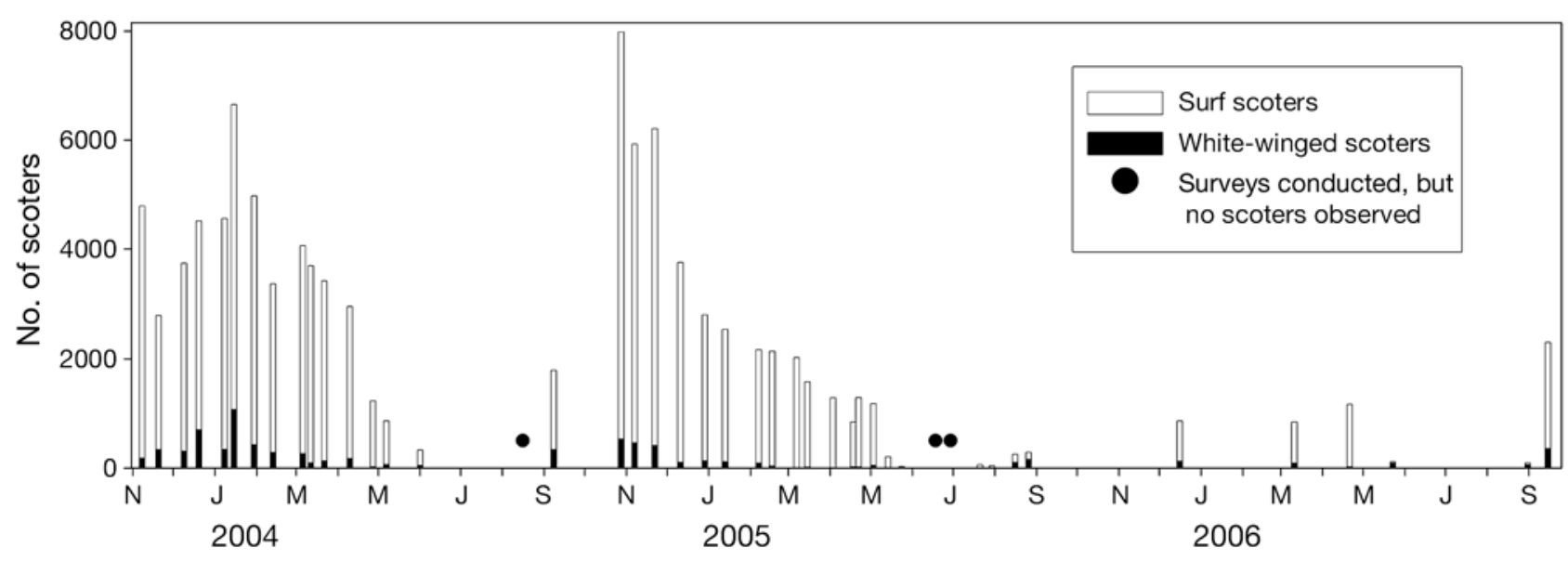

Fig. 2. Melanitta spp. Surveys of scoters in Penn Cove, Washington, USA, from 2003 to 2006 ( $\mathrm{n}=45$ surveys). The smaller number of surveys conducted in 2005 to 2006 was supplemented by regular informal observations that also indicated that the abundance of scoters was lower throughout that winter

peatedly very near a gray whale. The whale appeared to be feeding because it was clearly making contact with bottom sediments at lower intertidal elevations. A fraction of the scoters on several occasions rapidly swam to within $5 \mathrm{~m}$ of the feeding whale before diving synchronously as a group. However, most of the diving activity by scoters occurred at least $100 \mathrm{~m}$ behind the whale but within its feeding path. Smaller numbers of other bird species were also present and feeding intermittently, including mainly glaucous-winged gulls Larus glaucescens and red-breasted mergansers Mergus serrator. We have not observed direct feeding associations between bottom-feeding birds and gray whales on other occasions. However, feeding along this shoreline is common for gray whales from March to May (Weitkamp et al. 1992; Fig. 1), and appears to become increasingly common for scoters in late winter and spring. For example, in this same location we observed diving activity by about 300 surf scoters on 27 March 2006, and 450 surf scoters and 50 white-winged scoters on 29 March 2007.

We collected surf scoters on 10 to 11 December 2005 (n = 9) and 17 March 2006 ( $n=10)$ using shotguns from small boats. Body composition was analyzed according to Afton \& Ankney (1991) by the Long Point Waterfowl and Wetlands Research Fund Avian Energetics Lab, Port Rowan, Ontario. Composition estimates for each bird were corrected for pre-analysis removal of the liver, kidneys, gizzard, and esophagus as in Lovvorn et al. (2003). For plasma metabolites, we used a sterile 12 gauge needle to collect $\sim 3 \mathrm{ml}$ of heart blood. Blood was placed in heparinized vials and temporarily stored on ice. Plasma and cellular fractions were separated by centrifugation within $12 \mathrm{~h}$ and stored at $-20^{\circ} \mathrm{C}$. We analyzed concentrations of true triglycerides (Sigma TR0100), $\beta$-hydroxybutyrate, and uric acid (Stanbio
Laboratory Procedures 2440 and 1045) using spectrophotometric assays (Beckman DU-64 Spectrophotometer). In just 3 mo during the winter of 2005 to 2006, body mass, lipid, and protein declined significantly (Fig. 3a), and plasma concentrations of triglycerides decreased while $\beta$-hydroxybutyrate and uric acid concentrations increased (Fig. 3b).

\section{DISCUSSION}

Every year a variable number of gray whales Eschrichtius robustus, some of which are thought to be in poor condition and have not been previously identified, enter Puget Sound during spring and summer (Calambokidis et al. 2000, 2002a). A fraction of these whales have returned annually to feed in Puget Sound since observations began in 1990, including at least 5 whales typically observed near Whidbey Island (Fig. 1) from March until May (the period of northward whale migration). This latter group of whales feeds mainly on ghost shrimp Neotrypaea californiensis, which occur in mid- to low-intertidal habitats adjacent to Penn Cove at a wet mass 2 to 15 times greater than for any other prey taxa reported for gray whales (Weitkamp et al. 1992).

Suction sieving by gray whales creates elliptical pits in bottom sediments that are typically $10 \mathrm{~cm}$ deep and up to $5 \mathrm{~m}^{2}$ in area (Oliver et al. 1984, Weitkamp et al. 1992). Such excavations likely enhance short-term foraging profitability for avian benthivores by exposing or dislodging infauna, and by attracting invertebrate scavengers that are also eaten by the birds. Near Sandy Point (Fig. 1), standing stocks of ghost shrimp are very high (1000 to $2000 \mathrm{~g} \mathrm{~m}^{-2}$ wet mass) and comprise 55 to $85 \%$ of the total wet mass of benthic macro- 

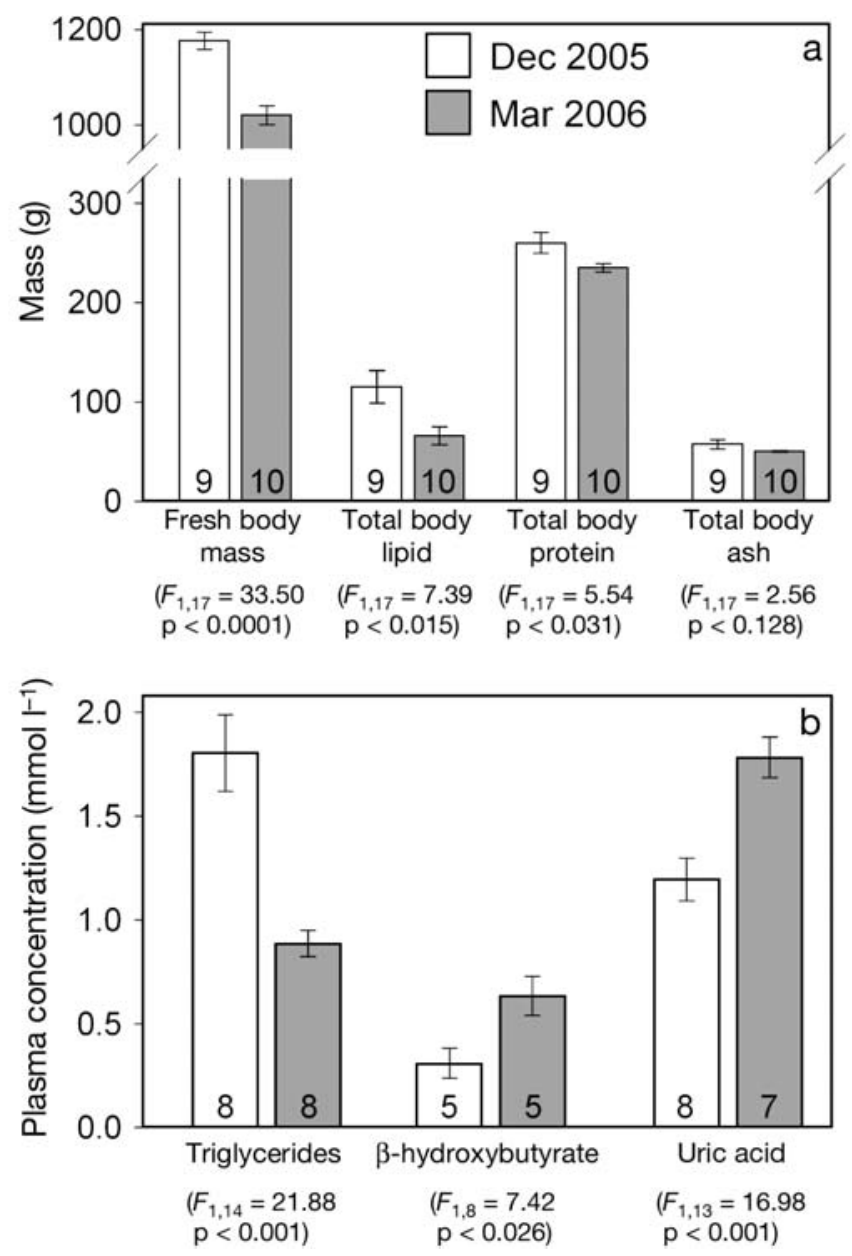

Fig. 3. Melanitta perspicillata. Seasonal (a) body composition and (b) plasma metabolites (mean $\pm \mathrm{SE}$ ) for after-hatch-year male surf scoters collected in Penn Cove from 2005 to 2006 (numbers in bars are sample sizes, and all test scores are for 1-way ANOVA)

fauna (Weitkamp et al. 1992). Although gray whales remove much of the prey biomass within feeding pits, the fraction of infauna that is dislodged and not consumed by gray whales is typically valuable to marine birds (Obst \& Hunt 1990). Ghost shrimp rarely emerge from deep burrows (Stevens 1929), and are thus likely unavailable to scoters Melanitta spp. unless sediments are disturbed. Within seconds after feeding pits are created, scavenging invertebrates (particularly lysianassid amphipods, which are distributed along the entire Pacific coast of North America) arrive to feed on injured and dislodged infauna; such aggregations of scavengers may be 30 times more abundant than in adjacent undisturbed areas (Oliver \& Slattery 1985). The scoters we observed may have fed mostly at a distance behind the whale to allow scavenging invertebrates to attain greater densities or dislodged prey to settle.
Foraging profitability for avian benthivores may be altered for prolonged periods after feeding by gray whales. In the Bering Sea and coastal British Columbia, invertebrate colonists settled in organic debris trapped in whale feeding pits and remained at elevated densities for weeks to months (Oliver \& Slattery 1985). Populations of some infaunal invertebrates may also increase over longer periods because sediment suspension by gray whales exports finer particles and releases nutrients (Johnson \& Nelson 1984). Longerterm changes in benthic communities may explain why, after the typical arrival in March of gray whales in Puget Sound, we observed scoter numbers increase in a habitual feeding area for whales. The period for which feeding pits are valuable to avian benthivores will depend on various factors affecting foraging profitability, such as colonization rates and thus localized biomass of prey (Oliver \& Slattery 1985), use of pits as visual cues, and feeding rates of other predators. In contrast, enhanced foraging for birds that feed at the water surface or in the water column requires suspension of foods, which is typically limited to $<30$ min after feeding activity of cetaceans (Obst \& Hunt 1990).

Declines in body reserves and changes in concentrations of plasma metabolites indicated that the physiological condition of surf scoters Melanitta perspicillata declined over winter in Penn Cove, a heavily used foraging site near habitual feeding areas for migrating gray whales. These indicators of poor feeding conditions corresponded to low use of Penn Cove in 2005 to 2006 (Fig. 2). Based on comparisons of the same data collected in other feeding areas for scoters in Puget Sound (E. M. Anderson unpubl. data), we hypothesize that seasonal declines in the profitability of key foods in Penn Cove triggered mid-winter departures of surf scoters from this important wintering site during other winters, such as 2003 to 2004 and 2004 to 2005. In years of poor feeding conditions, and in years when the profitability of foods is high in early winter and subsequently declines, alternative feeding opportunities (as afforded by whales) are likely critical for this significant fraction of the regional population of scoters.

We did not analyze scoter diets in areas where gray whales fed because our observation of the feeding association was opportunistic and we did not have permits to collect scoters in these locations. However, diet studies from other locations indicate that surf scoters would likely consume acceptable sizes of any invertebrate taxa made available by feeding activities of whales. In particular, surf scoters consume diverse crustaceans and other benthic invertebrates (Savard et al. 1998). Moreover, surf scoters are highly opportunistic foragers, taking advantage of ephemeral foods with seasonal availabilities that are either predictable such as spawn of Pacific herring Clupea pallasi (Vermeer 
1981), or unpredictable such as reproducing polychaetes (Lacroix et al. 2005). In addition to scoter diet analyses, data complementary to our local bird counts and measures of scoter physiological condition are needed to confirm that gray whales enhance scoter foraging for prolonged periods. Questions include whether scoter movements in spring correspond to whale distributions, and whether scoter physiological condition differs between areas with and without feeding whales.

Recent episodes of high mortality for gray whales during migration and winter may have resulted from observed declines of their main prey in the Bering Sea (Le Boeuf et al. 2000). Possible reasons for declines in prey there, as well as for gray whale expansion of foraging sites elsewhere, include reduced productivity of Bering Sea prey (Moore et al. 2003) and increase of the whale population to carrying capacity (Highsmith et al. 2006). Gray whales that feed throughout the summer south of the Bering Sea are known as the Pacific Coast Feeding Aggregation, and likely account for just 1 to $2 \%$ of the $\sim 18000$ gray whales in the eastern Pacific Ocean (Calambokidis et al. 2002a, Angliss \& Outlaw 2007). However, foraging during migration occurs along the entire Pacific coast. Feeding pits reach densities of $1000 \mathrm{~km}^{-1}$ of shoreline in some intertidal areas of Puget Sound (Weitkamp et al. 1992), and $>30 \%$ of shallow subtidal areas may be covered by whale excavations along portions of the west coast of Vancouver Island, British Columbia (Kvitek \& Oliver 1986). At the scale of decades, gray whales may feed along all suitable sections of coast, shifting foraging locations as profitability changes among diverse foods (Darling et al. 1998). These impacts can alter prey availability for several months (Oliver \& Slattery 1985), and thus we suggest that longer-term effects on many bottom-feeding animals may be important, even if direct feeding associations with gray whales are rare. Moreover, feeding by gray whales during their northward migration coincides with increasing energy needs of marine birds as they prepare for migration and reproduction, at the same time that typical winter foods may have declined (Lewis et al. 2007). If numbers of Pacific gray whales were indeed far greater in the past as suggested by recent genetic analyses (Alter et al. 2007), interactions such as the one reported here may have historically been major factors in the foraging strategies and trophic relations of a range of bottom-feeding vertebrates.

Acknowledgements. This paper is dedicated to M. H. Anderson (1943 to 2007) for making gray whale observations possible. We thank C. H. Peterson and D. Esler for valuable comments on an earlier draft of this paper. R. S. Smith helped produce figures. This study was funded by the US Fish and Wildlife Service Western Washington Fish and Wildlife Office
(No. 13410-5-J008), the Sea Duck Joint Venture (No. 701816M183), the SeaDoc Society (No. K004431-19), the National Science Foundation Office of Polar Programs (No. OPP-9813979 and No. ARC-0454454 to J.R.L.), and fellowships to E.M.A. from the National Oceanic and Atmospheric Administration National Estuarine Research Reserve System (Graduate Research Fellowship, No. NA03NOS4200048) and from the Wyoming National Aeronautics and Space Administration Space Grant Consortium, Wyoming NASA EPSCoR (No. NCC5-578).

\section{LITERATURE CITED}

Afton AD, Ankney CD (1991) Nutrient-reserve dynamics of breeding lesser scaup: a test of competing hypotheses. Condor 93:89-97

Alter SE, Rynes E, Palumbi SR (2007) DNA evidence for historic population size and past ecosystem impacts of gray whales. Proc Natl Acad Sci USA 104:15162-15167

Angliss RP, Outlaw RB (2007) Alaska marine mammal stock assessments, 2006. NOAA Tech Memo 168:141-150

Calambokidis J, Schlender S, Gosho M, Gearin P, Goley D, Toropova C (2000) Gray whale photographic identification in 1999: collaborative research by Cascadia Research, the National Marine Mammal Laboratory, and Humboldt State University. Cascadia Research Collective, Olympia, WA

Calambokidis J, Darling JD, Deecke V, Gearin P and others (2002a) Abundance, range and movements of a feeding aggregation of gray whales Eschrichtius robustus from California to southeastern Alaska in 1998. J Cetacean Res Manag 4:267-276

Calambokidis J, Gosho M, Gearin P, Darling JD and others (2002b) Gray whale photographic identification in 2001: collaborative research in the Pacific Northwest. Cascadia Research Collective, Olympia, WA

Darling JD, Keogh KE, Steeves TE (1998) Gray whale (Eschrichtius robustus) habitat utilization and prey species off Vancouver Island, B.C. Mar Mamm Sci 14:692-720

Evans PGH (1982) Associations between seabirds and cetaceans: a review. Mamm Rev 12:187-206

Grebmeier JM, Harrison NM (1992) Seabird feeding on benthic amphipods facilitated by gray whale activity in the northern Bering Sea. Mar Ecol Prog Ser 80:125-133

Harrison CS (1979) The association of marine birds and feeding gray whales. Condor 81:93-95

Highsmith RC, Coyle KO, Bluhm BA, Konar B (2006) Gray whales in the Bering and Chukchi Seas. In: Estes JA, Demaster DP, Doak DF, Williams TM, Brownell RL Jr (eds) Whales, whaling and ocean ecosystems. University of California Press, Santa Cruz, p 303-313

Johnson KR, Nelson CH (1984) Side-scan sonar assessment of gray whale feeding in the Bering Sea. Science 225: 1150-1152

Kvitek RG, Oliver JS (1986) Side-scan sonar estimates of the utilization of gray whale feeding grounds along Vancouver Island, Canada. Cont Shelf Res 6:639-654

Lacroix DL, Boyd S, Esler D, Kirk M, Lewis T, Lipovsky S (2005) Surf scoters Melanitta perspicillata aggregate in association with ephemerally abundant polychaetes. Mar Ornithol 33:61-63

Le Boeuf BJ, Pérez-Cortés H, Urbán RJ, Mate BR, Ollervides UF (2000) High gray whale mortality and low recruitment in 1999: potential causes and implications. J Cetacean Res Manag 2:85-99

Lewis TL, Esler D, Boyd WS (2007) Effects of predation by sea ducks on clam abundance in soft-bottom intertidal habitats. Mar Ecol Prog Ser 329:131-144 
Lovvorn JR, Richman SE, Grebmeier JM, Cooper LW (2003) Diet and body condition of spectacled eiders wintering in pack ice of the Bering Sea. Polar Biol 26:259-267

Moore SE, Grebmeier JM, Davies JR (2003) Gray whale distribution relative to forage habitat in the northern Bering Sea: current conditions and retrospective summary. Can J Zool 81:734-742

Moore SE, Wynne KM, Kinney JC, Grebmeier JM (2007) Gray whale occurrence and forage southeast of Kodiak Island, Alaska. Mar Mamm Sci 23:419-428

Obst BS, Hunt GL Jr (1990) Marine birds feed at gray whale mud plumes in the Bering Sea. Auk 107:678-688

Oliver JS, Slattery PN (1985) Destruction and opportunity on the sea floor: effects of gray whale feeding. Ecology 66: 1965-1975

Oliver JS, Slattery PN, Silberstein MA, O'Connor EF (1984) Gray whale feeding on dense ampeliscid amphipod communities near Bamfield, British Columbia. Can J Zool 62: 41-49

Pierotti R (1988) Associations between marine birds and mammals in the northwest Atlantic Ocean. In: Burger J (ed) Seabirds \& other marine vertebrates. Columbia University Press, New York, p 31-58

Pitman RL, Ballance LT (1992) Parkinson's petrel distribution and foraging ecology in the eastern Pacific: aspects of an

Editorial responsibility: Charles Peterson,

Morehead City, North Carolina, USA exclusive feeding relationship with dolphins. Condor 94: 825-835

Rice DW, Wolman AA (1971) The life history and ecology of the gray whale Eschrichtius robustus. Am Soc Mammalogists 3:1-142

Sánchez-Pacheco JA, Vázquez-Hanckin A, de Silva-Dávila R (2001) Gray whales' mid-spring feeding at Bahía de los Ángeles, Gulf of California, Mexico. Mar Mamm Sci 17: 186-191

Savard JPL, Bordage D, Reed A (1998) Surf scoter Melanitta perspicillata. In: Poole A, Gill F (eds) The birds of North America, No. 363. The Academy of Natural Sciences \& the American Ornithologists' Union, Philadelphia \& Washington, DC

Stevens BA (1929) Ecological observations on Callianassidae of Puget Sound. Ecology 10:399-405

Vermeer K (1981) Food and populations of surf scoters in British Columbia. Wildfowl 32:107-116

Weitkamp LA, Wissmar RC, Simenstad CA, Fresh KL, Odell JG (1992) Gray whale foraging on ghost shrimp Callianassa californiensis in littoral sand flats of Puget Sound, USA, Can J Zool 70:2275-2280

Welch H, Crawford RE, Hop H (1993) Occurrence of arctic cod Boreogadus saida schools and their vulnerability to predation in the Canadian High Arctic. Arctic 46:331-339

Submitted: August 6, 2007; Accepted: November 26, 2007 Proofs received from author(s): April 10, 2008 